\title{
The thymus gland in ancient Greek medicine
}

\author{
Konstantinos Laios ${ }^{1}$
}

Received: 20 August 2017 / Accepted: 9 February 2018 / Published online: 19 April 2018

(C) Hellenic Endocrine Society 2018

\begin{abstract}
The term thymus was used in ancient Greek medical literature to describe not only the thymus gland but also the warty excrescences found mainly in the genitals or the anus, but also over the entire body. Rufus of Ephesus (1st-2nd c. AD) gave the earliest anatomical description of this gland in humans, while Galen (1st-2nd c. AD) first described it in animals. However, the origins and meaning of this term have long mystified researchers. A careful investigation into its etymology together with the information derived from early anatomical descriptions has enabled us to propose a new interpretation of the origins of the name of the thymus gland.
\end{abstract}

Keywords Thymus gland · Rufus of Ephesus · Galen · Joannes Galenus

\section{Introduction}

The origins of the term "thymus" (Greek: $\theta \dot{v} \mu \mathrm{s})$ to describe the thymus gland have baffled researchers. In Indo-European linguistics, the PIE root *dheu (1) meaning 'vapor, fumes,' formed the basis for a large number of words throughout the I. E. languages possessing the basic literal meaning of "to rise in a cloud," for example, Latin fumus, smoke, steam [1]. In Greek, it produced both literal and metaphorical meanings: the verb $\theta \dot{v} \omega$ (to sacrifice, which initially had the meaning of making smoke), the noun $\theta v \mu$ ó $\varsigma$ (having two meanings, both literally fume but also metaphorically mental effervescence, anger, passion, spirit, and the place of the soul situated in the heart, the "breath" of the soul), the noun $\theta \dot{v} \mu \mathrm{v}$ and its diminutive $\theta v \mu \alpha \dot{\rho} \rho$ (=thyme, because this plant was burned and its fume odorized), the verb tó $\varphi \omega$ (to make smoke, become ash) and its noun tó $\varphi$ o (initially meaning to make smoke, and later the disease typhus), the noun $\tau v \varphi \lambda o ́$ (blind, meaning with blurred vision, in darkness), and finally the noun $\theta \dot{v} \mu \mathrm{s}$ (thymus gland) $[2,3]$. However, although the etymology and meaning of the other words were basically clear, the origins and the fundamental meaning of the noun $\theta \dot{v} \mu \varsigma_{\varsigma}$ to describe the thymus gland were not.

Konstantinos Laios

konstlaios@gmail.com

1 Medical School, National and Kapodistrian University of Athens, Athens, Greece

\section{Thymus in ancient Greek medicine and medical literature}

It should be borne in mind that in ancient Greek medical literature, the term thymus (Greek: $\theta \dot{v} \mu \mathrm{s})$ ), mostly in the plural form, that is thymoi (Greek: $\theta \dot{v} \mu \mathrm{o}$ ), while being used to describe the thymus gland, mainly referred to warty excrescences or outgrowths that may be seen in the genitals or the anus, though generally throughout the body. This term was used due to resemblance of the outgrowths to the thyme (Pseudo-Galenus Med. Definitiones medicae 19.444.7-8) [4].

The earliest medical description of the thymus gland is found in the work of Rufus of Ephesus (1st-2nd c. AD) who described the thymus as a gland located over the heart, before the seventh thoracic spondyl and also before the end of the bronchus which reaches the lung. Rufus of Ephesus also noted that this gland is not seen in every man (Rufus Med. De corporis humani appellationibus 168.1-169.1) [5]. A similar description is additionally found in the work of Julius Pollux (2nd c. AD) (Julius Pollux Gramm. Onomasticon 2.218.2-4) [6]. Galen (1st-2nd c. AD) also described this gland in animals, writing that the thymus should not be considered as a small-sized gland, it being large in new-born animals but becoming smaller and harder when they have matured, thereby describing the involution of the gland (Galenus Med. De alimentorum facultatibus libri iii 6.674.3-9) [7].

Of great interest is the reference to the thymus by Joannes Galenus (14th c. AD), who was not a physician but a philosopher, considered to be a Hypatus Philosophorum (chief of the 
philosophers) while also holding the office of chartophylax (keeper of the records) of the province of Justiniana Prima and of all Bulgaria under the Byzantine emperor Andronicus Palaeologus the Younger (1328-1341 AD) [8]. In his commentary on the Iliad, and specifically of verse $\Upsilon 406$ (Homer Ilias 20.406) [9], where Achilles strikes Polydorus with his spear, Joannes Galenus wrote that the thymus was a gland located between the two collar bones for the protection of the trachea from injury (Joannes Galenus Scholia in Iliadem 20.406a.1-6) [10].

Taking into consideration all the above information, we can now propose an explanation for the origins and meaning of the term thymus to describe the thymus gland. The fact that ancient Greek and Byzantine physicians clearly used the term thymus mainly in its plural form, thymoi, to describe the warty excrescences found in the genitals and the anus and, as added by the Byzantine physicians, in every part of the human body (Oribasius Med. Collectiones medicae 45.12.1.1-45.12.2.4) [11], leads us to believe that the term described two different anatomical elements, i.e., warty excrescences as well as the thymus gland. This distinction points to the possibility that the term thymus to denote the thymus gland had different origins from the term thymus or thymoi signifying the warty excrescenceswhich were likened to the appearance of the plant, the thyme.

In our view, the key element clarifying the naming of this organ is the observation of its involution. Galen, as mentioned above, clearly described this phenomenon in animals. Since Galen's anatomical experience was derived mainly through dissections in animals [12], we would not expect this specific observation in humans. On the other hand, Rufus of Ephesus, who also had little experience in human dissections [13], noticed that this gland could not normally be observed in adults. However, given the limitations in human dissections in antiquity, it was virtually impossible to perform dissections in children; therefore, it was much more difficult for Rufus of Ephesus to make a similar observation regarding thymus involution in humans as had Galen in animals.

Nevertheless, the observation of the involution of the thymus, or, as it was described by ancient Greek physicians, its decrease or "disappearance" (probably because it was difficult for ancient anatomists to dissect such a small organ), permits us to link the name of this organ with the idea of vapor and evaporation.

\section{Conclusions}

Although ancient Greek physicians dealt with the topographical anatomy of the thymus gland, neither they nor the Byzantine physicians wrote about its functional role [14]. The only references regarding its function found in Joannes Galenus' commentary should not be considered valid, since he was not a physician. Nonetheless, his description of the gland's function probably reveals the difficulty the ancient Greek and Byzantine physicians had in attempting to define a specific role for this organ.

\section{Compliance with ethical standards}

Conflicts of interest The authors declare that they have no conflict of interest.

\section{References}

1. Hofmann JB (1950) Etymologisches Worterbuch des Griechischen. R. Oldenburg, Munchen

2. Babiniotis G (2009) Modern Greek language dictionary. History of words, Athens Teaching Center

3. Liddell HG, Scott R (1940) A Greek-English lexicon. Revised and augmented throughout by sir Henry Stuart Jones with the assistance of Roderick McKenzie. Clarendon Press, Oxford

4. Kuhn CG (1830) Claudii Galeni opera omnia, Definitiones medicae, vol 19. Knobloch, Leipzig

5. Daremberg C, Ruelle CE (1879) Oeuvres de Rufus d'Ephese, De corporis humani appellationibus. Imprimerie Nationale, Paris

6. Bethe E (1900) Pollucis onomasticon. Teubner, Leipzig

7. Helmreich G (1923) Galeni de alimentorum facultatibus libri iii. Teubner, Leipzig

8. Smith W (1876) Dictionary of Greek and roman biography and mythology. J. Murray, London

9. Allen TW (1931) Homeri Ilias. Clarendon Press, Oxford

10. Flach H (1876) Glossen und Scholien zur hesiodischen Theogonie. Allegoriae in Homeri Iliadem 4.1-4. Teubner, Leipzig

11. Raeder J (1928-1933) Oribasii collectionum medicarum reliquiae. Teubner, Leipzig

12. Prioreschi P (1998) A history of medicine. Roman Medicine. III. Horatius Press, Omaha

13. Gersh CJ (2012) Naming the body: a translation with commentary and interpretive essays of three anatomical works attributed to Rufus of Ephesus. PhD Thesis, University of Michigan

14. Hyrtl J (1880) Onomatologia Anatomica. Geschichte und Kritik der anatomischen Sprache der 